\title{
References
}

1. Archive of the project «Snyatyn - Archeology of memory: opening and attraction of the historical, cultural and artistic heritage of the Galician city». Center for Urban History of East Central Europe within the framework of the program «MEMORIA.Volunteers for the Preservation of Europe's Cultural Heritage.» [in Ukrainian].

2. Boyko, Ch. (2010). «Snyatin - Archeology of Memory»: Opening and Return of the Historical and CulturalArtistic Heritage of the Galician Town. Bulletin of the Kharkov State Academy of Design and Arts. Kharkiv: Center for Oriental Studies, 8, pp.11-34. [in Ukrainian].

3. Klymenyuk T.M.,\& Boyko, Ch.S. (2010). Architectural measurements and inventory of monuments. Lviv: Polytechnic Publishing House. [in Ukrainian].

4. Curatorium of the guardianship of Jewish art monuments under the Board of the Jewish Religious Community in Lviv. Instruction on the rules for the execution and installation of gravestones in cemeteries. Central State Historical Archive of Ukraine in Lviv: 1925-1928. F.701, D.3, p.713. Sh.3. [in Polish].

5. Martin, M. (2011). Inscriptions on objects from the collection of Judaism LMIR. Bulletin of the Museum of the History of Religion, 9, pp. 67-72. [in Ukrainian].

6. Nosonovsky, M. (1998). Jewish Hebrew epigraphic monuments of Ukraine. Proceedings of the Tirosh «Second Youth Conference on Judaica» (pp.117-122) Moscow. [in Russian].

7. Nosonovsky, M. (1997-2002). «Tied in a knot of life»: to the poetics of the Jewish epitaphs. Retrieved from http://berkovich-zametki.com/Nomer19/MN18.htm

8. Nosonovskiy, M. (1994). On epitaphs from Jewish gravestones of Right-Bank Ukraine. History of Jews in Ukraine and Belarus. pp. 107 - 119. St. Petersburg. [in Russian].

9. Nosonovsky, M. (1999). Epitaph of the XVI century from the Jewish gravestones of Ukraine. Monuments of culture. New discoveries (writing, art, archeology). Moscow: Science, pp.86-97. [in Russian].

10. Ritual Jewish silver from the funds of the Lviv Museum of Religion: catalog: author-compiler Martin, M. (2018). Lviv: Loghos. [in Ukrainian].

11. Scripture of the Old and New Testaments: complete translation of the original Jewish, Aramaic and Greek texts. (1991). Ukrainian Bible 63 DC. United Bible Societies - 60 M. Pentateuch .pp. 3-177. [in Ukrainian].

12. Haimovich, B. (1994). Historical and ethnographic expeditions of the St. Petersburg Jewish University. History of Jews in Ukraine and in Belarus. (pp. 15 - 43) St. Petersburg. [in Russian].

Стаття надійшла до редакиії 2.09.2019 Прийнято до публікаиії 1.10.2019

Несен Ірина Іванівна,

кандидат історичних наук, доцент, доцент кафедри мистецтвознавчої експертизи Національної академї керівних кадрів культури і мистецтва ORCID 0000-0002-9804-9659 iryna.nesen@gmail.com

\section{УКРАЇНСЬКЕ НАРОДНЕ ЖИТЛО В КОНТЕКСТІ ПРОБЛЕМИ СИНТЕЗУ МИСТЕЦТВ}

Метою дослідження є системний аналіз народного житла як цілісної моделі, у якій взаємодіють три найважливіші чинники - конструкція, форма i декор, а також з'ясувати найважливіші регіональні характеристики таких моделей. Методологія дослідження грунтується на поєднанні крос-культурного, типологічного, мистецтвознавчого підходів і семіотичного аналізу. Наукова новизна полягає у відстеженні головних напрямів і тенденцій змін регіональних образів житла. Висновки. Внаслідок проведеного дослідження 3'ясовано, що головними чинниками стилістики традиційного житла українців є майстерне володіння різноманітними технічними прийомами обробки матеріалів, насиченість фасаду й інтер'єру оздобленнями й художніми виробами; згармонізованістю конструкції, форми і декору. Кожен із 5 виділених у статті регіонів мав власний образ житла, який на українських теренах змінювався у напрямку з півночі на південь. Народне житло століттями існувало як самодостатня екологічна система, органічно вписана у навколишній ландшафт, живописно підкреслюючи і розвиваючи його.

Ключові слова: народне житло, архітектоніка, інтер'єр, регіональні конструктивно-оздоблювальні варіанти житла, синтез мистецтв, етнодизайн.

(C) Несен I.I., 2019 
Несен Ирина Ивановна, кандидат исторических наук, дочент кафедры искусствоведческой экспертизы Национальной академии руководящих кадров культуры и искусства

Украинское народное жилище в контексте проблемы синтеза искусств

Целью исследования является системный анализ народного жилья как целостной модели, в которой взаимодействуют три важнейшие факторы - конструкция, форма и декор, а также выяснить важнейшие региональные характеристики таких моделей. Методология исследования основана на сочетании кросскультурного, типологического, искусствоведческого подходов и семиотического анализа. Научная новизна заключается в отслеживании основных направлений и тенденций изменений региональных образов жилья. Выводы. Вследствие проведенного исследования установлено, что главными факторами стилистики традиционного жилища украинцев является мастерское владение различными техническими приемами обработки материалов, насыщенность фасада и интерьера отделкой и художественными изделиями; гармоничность конструкции, формы и декора. Каждый из 5 выделенных в статье регионов имел собственный образ жилья, который на украинской территории менялся в направлении с севера на юг. Народное жилье веками существовало как самодостаточная экологическая система, органично вписана в окружающий ландшафт, живописно подчеркивая и развивая его.

Ключевые слова: народное жилье, архитектоника, интерьер, региональные конструктивноотделочные варианты жилья, синтез искусств, етнодизайн.

Nesen Irina, Candidate of Historical Sciences, Associate Professor of the Department of Art Study Expertise of the National Academy of Cultural and Arts Management

Ukrainian national housing in the context of problems of the arts synthesis

The purpose of the article is a systematic analysis of people's housing as a holistic model, which combines the three most important factors - design, shape, and decoration. As well as to find out the most critical regional characteristics of such models. The methodology of the study is based on the combination of cross-cultural, typological, art-study approaches, and semiotic analysis. Scientific Novelty is to track the main trends and trends of regional change patterns of housing. Conclusions. As a result of the study, it was discovered that the main factors of the style of the traditional house of Ukrainians are smart possession of a variety of techniques of materials processing, a saturation of the facade and interior by decorations, and artistic products - harmony of design, shape, and decoration. Each of the five regions described in the article had its image of housing, which varied from north to south on Ukrainian terrains. The monochrome interior and exterior characterize the northern (Polissian and Podlaski) types. The invoice of the facade was formed here by a log cabin of timber. The interior walls were washed or plastered by yellow clay. Western (Carpathian) type was characterized by the monochrome of the interior, enlivened by decorative accents (carved or burnt sarcophagus chests, tiled stoves, decorative fabric on a pole, and images). The central (forest-steppe) type had local features on the right bank and the left bank and represented a generalized ethnic type of housing for Ukrainians. The southern (steppe) type was characterized by a particular system of paintings and complicated housing plans. People's homes have existed for centuries as an efficient ecological system that was organically inscribed in the surrounding landscape, underlining, and developing it.

Key words: folk dwelling, architectonics, interior, regional design and finishing options for housing, synthesis of arts, ethno-design

Актуальність дослідження. Синтез мистецтв як галузь наукових знань, що досліджує мистецтво взаємодії, дозволяє системно аналізувати складні художні об’єкти і явища у повноті їх численних взаємозв'язків і поширювати науково-аналітичні методи мистецького синтезу в нові галузі, зокрема, в народну архітектуру насамперед житлову і відкривати нові можливості розуміння загальних законів творення традиційної конструкції, іiі взаємозв’язок із формою й оздобленням, а також численні локальні варіанти образів народного житла. Тема відкриває шляхи розвитку етнодизайну й екологічного житла.

Стан наукової розробки проблеми. Народне житло українців у вітчизняній науці тривалий час досліджувалося окремими напрямками, серед яких насамперед висвітлювався архітектурноконструктивний контекст. Тому спершу з'явились узагальнюючі дослідження П. Юрченка, В. Самойловича, С. Таранушенка [9; 14]. У подальшому архітектори поглиблено вивчали регіональні будівельні традиції. До цього насамперед долучились А. Данилюк, С. Верговський, Р. Радович, які, зокрема звертали особливу увагу на цілісність й естетичність у сприйнятті фасаду, єдність пропорцій стін і даху, характеристики пластики й абрисів даху [2; 3; 4; 8].

Водночас у вітчизняній науці було започатковано вивчення семіотики народного житла, його символічно-обрядовий контекст. Численні польові матеріали засвідчили, що найважливіші частини житла (насамперед покуть) виокремлювалися ритуальними діями уже в ході будівництва [7; 9]. Світоглядну, а відтак символічну основу мали зони житла, архітектурні елементи (сволок), меблі, предмети побуту i, нарешті, орнаментальні системи житла, створені розписом або різьбленням. Однак, на сьогодні народне житло ще недостатньо узагальнене як цілісна світоглядна модель, у якій нерозривно поєднались конструкція, форма, декоративні і ритуальні системи, предметне наповнення. 
Мета статті. Застосовуючи міждисциплінарний контекст і поєднавши крос-культурний, типологічний, мистецтвознавчий методи, а частково семіотичний аналіз, у даній статті ми маємо на меті розглянути народне житло як цілісну етнокультурну модель, у якій взаємодіють три найважливіші чинники - конструкція, форма i декор; з'ясувати найважливіші регіональні характеристики традиційного житла українців відстежити головні напрями змін регіональних образів житла.

Виклад основного матеріалу. Українська хата давно набула узагальненого образу, навіяного поезіями XIX - початку XX ст. Переважна більшість уявляє їі невеликою, біленою, під солом'яним дахом, з малими вікнами і низькими дверима. Натомість типологія селянського житла обумовлена його горизонтальним плануванням. Історично воно розвивалося від однокамерного до багатокамерного. У XIX ст. усі відомі в Україні типи співіснували. Найпоширенішим було трикамерне побілене зрубне або каркасне житло типу «хата - сіни - комора» 3 чотирисхилим солом'яним дахом, дверима у центрі стіни, сонячною орієнтацією вікон, симетричним розташуванням відносно сіней житлової і господарської клітей.

Регіонально стилістика житла мала варіанти, обумовлені традиціями використання місцевих матеріалів і технічних прийомів. Житлові пропорції виробилися з урахуванням певних кліматичних умов і ландшафту. Відповідно до цього в Україні виділено 5 зональних субетнічних типів народної архітектури - північний (поліський), центральні лісостеповий правобережний i лівобережний, західний і південний. Кожна з зон має відповідні варіанти. У поліській зоні було виділено три субрегіональні варіанти - волинський, північно-київський і чернігівський; центральна лісостепова правобережна зона охоплює південноволинський, львівський, подільський i південнокиївський варіанти; центральна лісостепова лівобережна - включає полтавський і слобожанський. Південна (степова) - відповідно дніпропетровсько-дунайський, нижньодніпровський (причорноморський) i приазовський варіанти. Західна - включає карпатський, прикарпатський (покутський), східнокарпатський (гуцульський), західноприкарпатський (бойківський), західнокарпатський (лемківський i верховинський варіанти) [6, 164]. Тому не дивно, що на тлі існування східнослов'янських (головні конструктивно-архітектурні прийоми) й українських ознак житла (зруб чи каркас, система побілки, виділення архітектурних елементів підводками або розписами, конструктивне членування інтер'єру житла), кожен регіон в Україні сформував власний образ житла 3 особливостями форми даху, покрівельних матеріалів, фактури і колористики фасаду, планування і пропорцій житла. В одній з розвідок А. Данилюк зазначив: «Між покрівельним матеріалом і формою даху існує певний взаємозв'язок. Солом'яні дахи переважають у Волинській, Київській, Чернігівській і частково Житомирській та Рівненській областях; дерев'яні - в північно-східних районах Рівненської та північних і північно-західних районах Житомирської областей. Тут переважають двосхилі дахи, а там, де солом'яні - чотирисхилі» [3, 41].

Стилістика народного житла поєднує дві головні тенденції - тектонічну й декоративну. Попри універсальні параметри композиції житла, його естетичні принципи у кожній місцевості мали локальні вирішення, обумовлені низкою факторів - пропорціями, пластикою найважливіших конструктивних елементів, оздобленням. Розглянемо їх послідовно. У будівельних пропорціях втілилася давня антропоморфна метричність. Ї̈̈ застосування створило особливу народну архітектоніку житла. У кожному регіоні вона отримала особливості, пов'язані 3 варіантами планування, розмірами і масштабами. Часом дослідники фіксували застосування в народному будівництві українців правил «золотого перерізу». Однак, найчастіше ми стикаємось із низкою регіональних варіантів інших параметрів узгодження між житловим об'ємом і дахом.

Так, на півночі Українського Полісся дах був помітно нижчим за висоту стін і доволі пласким. Покрівельними матеріалами тут були житня солома або колота дошка. Висота зрубу стін поліської хати дорівнювала половині довжини стіни. Висота будівлі - меншою від довжини стіни зрубу. У Карпатах побутували різні типи дахів і пропорції. Найоригінальнішим явищем місцевого будівництва дослідники визнають бойківську хату. Саме на Бойківщині у трикамерних житлах застосування правила «золотого перерізу» було виявлене у поєднанні архітектурних величин. Дахи тут поєднували виразну динаміку і живописну м'якість обрисів $[6,80]$. Натомість гуцульські житла відзначені графічністю структурних членувань і загальною монохромністю колориту. Крім солом'яних парків усталеними покрівельними матеріалами в Українських Карпатах були гонт i драниця. Різниця покрівельних матеріалів обумлювалася специфікою господарства і природних ресурсів. У землеробських районах - переважали стрімкі конічні солом'яні дахи. У скотарському господарстві гуцулів побутував «гонт». Найбільша різниця величин між дахом і стіною на західноукраїнських теренах зафіксована на півдні Холмщини $-2: 1[8,121]$. 
На Поділлі висоти стіни і даху були практично однаковими. Такі ж пропорції побутували на Наддніпрянщині. А солом'яні покрівлі тут мали кут нахилу $45^{\circ}$. Зважаючи на те, що на Правобережній Наддніпрянщині та Поділлі солом'яні парки на кутах даху укладалися уступами, а вгорі намощувався товстий гребінь, пластика верхів помітно відрізнялася від покрівельної традиції Лівобережної Наддніпрянщини, де кути даху не виділяли, а навпаки пом'якшували і скругляли. Ця диференціація зберігалась також на правобережжі й лівобережжі Південної України. У кожному випадку всі параметри були взаємопов’язаними і формували особливу архітектоніку споруд.

Пластика фасаду у різних місцевостях також мала локальні варіанти вирішення. На Поліссі фасади жител довший час були немащеними, що дозволяло бачити монохромний відкритий зруб. Його пластика ледь пожвавлювалася фактурою матеріалу - кругляка або плах і графікою вінцевих випусків. У лісостеповій частині України від Карпат до Слобожанщини фасади зазвичай збагачувалася конструктивними або декоративними засобами. Так, важливими конструктивними елементами житлового фасаду були піддашки і галереї $[13,130]$. Цей же прийом був відомий і у степовій частині України.

Тектонічне розв'язання стіни в українському житлі нерідко було пов'язане 3 декоративними прийомами розписів. Ця традиція у різних проявах упродовж століть існувала практично у всіх регіонах нашої держави. Так найпростіші оздоблювальні схеми у вигляді кольорових поперечних підводок кольоровими глинами побутували у північній поліській смузі. Крім широко вживаних оперізувань стіни вздовж призьби тут також застосовувалися розшивання смугами зрубу затильної стіни. Навколо вікон тут також застосовуали хвилясті широкі обводки або зкомпонований ланцюжком геометричний орнамент. Ці найпростіші мотиви у минулому мали глибокий символічний зміст, пов'язаний із темою вшанування померлих.

У лісостеповій і степовій смугах України оперізувальні підводки у вигляді контрастних за кольорами рівних, хвилястих або ламаних смуг над призьбою і вгорі під дахом також були широко вживані. Але тут вони поєднувалися 3 доволі складними оздоблювальними композиціями, ритмічно нанесеними на фасаді у різних локально поширених композиційних схемах [12, 24-25].

Найбільш поширеними були кілька типів: групи мотивів розташовані під дахом (Поділля); фризові композиції на кутах хати (Уманщина); крупні орнаментальні мотиви на одвірках або оздоблення на дверях (Західне Поділля, Прикарпаття). Усі варіанти оздоблювальних схем безпосередньо пов'язані 3 тектонікою стіни, а отже органічно злиті 3 архітектурою. Локального поширення в оздобленні фасадів Поділля на межі XIX - XX ст. також набуло личкування гіпсом або алебастром, яке дозволяло застосовувати різноманітні штампи, якими створювали декоративні конрельєфні фактури площин стіни. Застосування такого личкування також дозволяло введення окремих поліхромних мотивів на кутах або навколо дверних пройомів. Оздоблені штампами поверхні поєднувалися 3 низкою архітектурних елементів - пілястами і карнизами, які формували конструктивнооздоблювальну систему фасаду. Для захисту від вологи виконане личкування вкривали вапном.

Стилістика екстер'єру нерозривно пов'язана з інтер'єром житла і господарських частин. Житлова частина повсюдно в Україні мала сталу організацію взаємних розташувань. Ї̈̈ формували насамперед діагональ піч/покуть й обрамлення, що формували виставлені під чільною і причілковою стінами стаціонарні меблі (лави, спальний настил, стіл, посудна шафа). Рухомі меблі були відповідним наповненням (скриня (бодня), ослони, полиці, жердки). Традиційний інтер'єр можна було окинути одним поглядом ще 3 порогу. Зазвичай очі насамперед бачили «покуть» 3 декоративною колористикою рушників, що обрамлювали ікони, а далі - інші частини житла. Загальне сприйняття інтер'єру значною мірою пов'язане з його освітленням.

Однорідність в структурі інтер'єру поєднувалася з регіональною і локальною багатоманітністю оздоблювальних прийомів, форм і колористичних систем, а також предметів хатнього начиння. Звідси формувалася стильова варіантність образів житла, про яку не раз писали дослідники: «...інтер'єр хати гармонійний і досконалий з погляду конструкцій, а меблі в ньому виконують функцію внутрішньої архітектури, єдиного цілого, яке протягом дня перетворювалося в їдальню, спальню і майстерню. Мірилом інтер'єру є сама людина, іiі уявлення про світотворення» $[4,70]$.

Слід розрізняти оздоблювальні прийоми для нижньої, середньої і верхньої частин житла. Їх співіснування і співвідношення формують відповідну ритміку у розвитку інтер'єру. Найбільш яскравим прикладом цьому $\epsilon$ Південне Поділля (колишня Кам'янеччина), де оздоблення розпочиналося з розмальовування долівки і далі піднімалося на стіни, затухаючи у горі. У більшості ж регіонів оздоблення нижньої частини було вкрай лаконічним (рівні і криволінійні підводки, живописна пляма кольору глиняної долівки). Середня частина зазвичай мала найбільшу кількість декору. Натомість у верхній частині для обрамлення використовували замкнені або фризові 
композиції, укладені з різних груп орнаментальних мотивів. Окремі системи існували для дверей (кольорові тонування, різьблення, розписи тощо), а також для вікон (кольорові підводки, різьблені деталі-«лиштви», віконниці, фронтони тощо).

3 погляду оздоблювальної стилістики народне житло також можна розділити на дві групи масово поширене тиньковане білими або кольоровими глинами і локально поширене небілене «мите». Зразки останньої групи у минулому були поширені на півдні Полтавщини, на Поліссі, у гуцулів і у деяких інших місцевостях. Але у кожному регіоні «мите» житло мало свої оздоблювальні системи та акценти - монохромність, створена лініями і площинами; поліхромність за рахунок створення живописних композицій; декоративні акценти засобами художньої майоліки.

В організації традиційного інтер'єру три найважливіші функціональні й сакральні вузли інтер'єру трикамерного житла - піч, покуть і «водник» - були водночас центрами декорування. Така традиція залишалася незмінною при поступовому перетворенні компактного плану (прямокутного) житла в ускладненний (квадратний), по мірі збільшення кількості житлових кімнат.

Піч безпосередньо була пов'язана зі спальною зоною і мурувалася під холодною (північнозахідної орієнтації) стіною. Тому не випадково, що у цій відпочинковій частині декором слугували насамперед різноманітні узорні тканини, що ними застеляли піл (або ліжко). Вони ефектно контрастували з білим (або кольору митого дерева) тлом стіни. Важливими у цьому контексті були також килими (у тих місцевостях, де вони побутували), які вивішували на жердці над полом або стінах біля нього. «Покуть» поєднувала у собі статус родини і святості, матеріальним втіленням яких слугували стіл, накритий узорною скатертиною і ікони під різноманітними рушниками. Нарешті «водник» був функціонально-сакральною точкою господарської зона. Тут простір організовувався взаємопов'язаним розташуванням посудної шафи і полиць по відношенню до печі. Кожен із названих вузлів мав свою колористику, що забезпечувалася основним кольором/тоном печі (не завжди білим Гуцульщина, Полісся), кольоровими підводками пічних карнизів, інших рельєфних іiі деталей, i узгоджувалася з грою барв розписного посуду (гончарного і порцелянового).

Регіональна стилістика інтер'єрів формувалася сталими засобами - естетикою форм і кольорів посуду, хатніх тканин і малюванням, які суттєво різнилися в окремих місцевостях. 3-поміж названих засобів розписи відігравали найважливіше загально-організуючу роль. Вони здавна побутували у лісостеповій і степовій частинах України $[1 ; 10]$. Найбільшими осередками тут були Кам'янеччина, Уманщина, Південна Полтавщина і Північна Дніпропетровщина. У Західній Україні і Поліссі побутували різноманітні системи кольорових підводок, які графічно підкреслювали загальний приглушений коричневий або й чорно-сірий колорит стін.

Висновки. Неповторність стилістики народного житла українців минулих століть грунтується на кількох чинниках: майстерному його виготовленні вручну від конструкції до деталей; насиченість фасаду й інтер'єру оздобленнями й художніми виробами; згармонізованістю конструкції, форми i декору, а також функції, ритуалістики i оздоблень. Взаємозв'язок архітектури i різноманітних ремесел в житлі грунтується на синкретичній ідеології народної традиції, колективно сформованої поколіннями українців. Просторову організацію української хати характеризує цілісність, контрасність і структурованість. У ній органічно втілена злагодженість об'ємного (просторового) і планового (площинного) співвідношень.

Стилістика житла окремого регіону/субрегіону існувала незалежно від типів його планувань. Кожен із 5 виділених регіонів мав власний образ житла, територіально зміни відбувалися з півночі на південь. Північний (поліський і підляський) тип характеризується монохромністю інтер'єру та екстер'єру. Фактуру фасаду тут формував зруб із колод або плах. Інтер'єр мав миті або мащені жовтою глиною стіни. Західний (карпатський) характеризувався монохромністю інтер'єру, пожвавленою декоративними акцентами (різьблені або випалені саркофагові скрині; кахляні печі; декоративна тканина на жердці й образах). Центральний (лісостеповий) тип мав локальні особливості на правобережжі й лівобережжі і представляє узагальнений етнічний тип житла українців. Південний (степовий), тип характеризувався особливою системою розписів і ускладненими плануваннями жител.

Jimepamypa $121-128$.

1. Бежкович А.С. Настінні розписи української хати. Народна творчість та етнографія. 1957. № 4. С.

2. Верговський С. Давнє народне будівництво Українського та білоруського Полісся. Народна творчість та етнографія. 1979. № 2. С. 74-80.

3. Данилюк А. Традиційна архітектура регіонів України: Полісся. Л.: Видавничий центр ЛНУ ім. Ів. Франка, 2001. 147 c. 
4.Данилюк А. Українська хата. К: Наукова думка, 1991. 110 с.

5. Жолтовский П.Н. О пропорциях в народном зодчестве Украинских Карпат. Советская этнография. 1975. № 6. С. 79-85.

6. Косміна Т.В. Традиції та інновації в архітектурі Києва та Київщини. Етнографія Києва та Київини. Традииіï і сучасність. К.: Наукова думка, 1986. С. 157-199.

7. Несен I.I. Етнографічними стежками Житомирщини. Волинський музей: історія $i$ сучасність. Науковий збірник. Вип. 4. Луцьк, 2009. С. 361-365.

8. Радович Р. Народне житло. Холмщина і Підляшшя. Історико-етнографічне дослідження. К.: Родовід, 1997. С. 116-133.

9. Самойлович В.П. Народна творчість в архітектурі сільського житла. К.: Держбудвидав, 1961. 341 с.

10. Сілецький Р.Б. Традиційна будівельна обрядовість українців. Л.: ЛНУ імені Івана Франка, 2011. 428 с.

11. Федоренко-Коляда В.Ю. Стінні розписи в Миколаївському та Херсонському районі. Архітектура Радянської України. 1938. № 4-5. С. 52-56.

12. Холостенко М.В. Форма, колір і живописна декорація. Архітектура Радянської Украӥни. 1938. № 6. C. $22-28$.

13. Чепелик В.П. Київський осередок розвитку народних традицій в архітектурі початку ХX ст. Етнографія Києва та Київщини. Традииї і сучасність. К.: Наукова думка, 1986. С. 128-157.

14. Юрченко П.Г. Дерев’яна архітектура України. К.: Будівельник, 1970. 192 с.

\section{References}

1. Bezhkovy`ch, A.S. (1957). Nastinni rozpy`sy` ukrayins`koyi xaty`. Narodna tvorchist` ta etnografiya. 4, 121-128 [in Ukrainian].

2. Verghovsjkyj, S. (1979). Davnje narodne budivnyctvo Ukrajinsjkogho ta bilorusjkogho Polissja. Narodna tvorchistj ta etnoghrafija. 2, 74-80 [in Ukrainian].

3. Dany`lyuk, A. (2001). Trady`cijna arxitektura regioniv Ukrayiny`: Polissya. - Lviv: Vy`davny`chy`j centr LNU im. Iv. Franka [in Ukrainian].

4. Dany`lyuk, A. (1991). Ukrayins`ka xata. Kyiv: Naukova dumka [in Ukrainian].

5. Zholtovsky`j, P.N. (1975). O proporcy`yax v narodnom zodchestve Ukray`nsky`x Karpat. Sovetskaya эtnografy`ya. 6, 79-85 [in Russian]

6. Kosmina, T.V. (1986). Trady`ciyi ta innovaciyi v arxitekturi Ky`yeva ta Ky`yivshhy`ny`. Etnografiya Ky`yeva ta Ky`yivshhy'ny`. Trady`ciyi i suchasnist`. Kyiv: Naukova dumka, 157-199 [in Ukrainian].

7. Nesen, I.I. (2009). Etnografichny`my` stezhkamy`Zhy` tomy`rshhy`ny`. Voly`ns`ky’j muzej: istoriya i suchasnist`. Naukovy`j zbirny`k (pp. 361-365). Lucz`k, 4 [in Ukrainian].

8. Radovy`ch, R. (1997). Narodne zhy`tlo. Xolmshhy`na i Pidlyashshya. Istory`ko-etnografichne doslidzhennya. Kyiv: Rodovid, 116-133 [in Ukrainian].

9. Samojlovych, V.P. (1961). Narodna tvorchistj v arkhitekturi siljsjkogho zhytla. - Kyiv: Derzhbudvydav [in Ukrainian].

10. Silecz`ky`j, R.B. (2011). Trady`cijna budivel`na obryadovist` ukrayinciv. Lviv: LNU imeni Ivana Franka [in Ukrainian].

11. Fedorenko-Kolyada, V.Yu. (1938). Stinni rozpy`sy`v My`kolayivs`komu ta Xersons`komu rajoni. Arxitektura Radyans`koyi Ukrayiny`. 4-5, 52-56 [in Ukrainian].

12. Xolostenko, M.V. (1938). Forma, kolir i zhy`vopy`sna dekoraciya. Arxitektura Radyans`koyi Ukrayiny`, 6. 22-28 [in Ukrainian].

13. Chepely`k, V.P. (1986). Ky`yivs`ky`j oseredok rozvy`tku narodny`x trady`cij v arxitekturi pochatku XX st. Etnografiya Ky`yeva ta Ky`yivshhy`ny`. Trady`ciyi i suchasnist`. Kyiv: Naukova dumka, $128-157$ [in Ukrainian].

14. Jurchenko, P.Gh. (1970). Derev'jana arkhitektura Ukrajiny. Kyiv: Budiveljnyk [in Ukrainian]. 